\title{
HUBUNGAN PENGETAHUAN DASAR KONSTRUKSI KAYU DENGAN HASIL BELAJAR PRAKTEK KERJA BANGKU DI SMKN 58 JAKARTA
}

\author{
Hasty Wulandari,., ${ }^{*}$, Daryati . ${ }^{2}$, R. Karsono,., ${ }^{3}$ \\ ${ }^{1}$ Alumni Pendidikan Teknik Bangunan, FT UNJ,Jakarta, Indonesia. \\ 2 Pendidikan Teknik Bangunan, FT UNJ, Jakarta, Indonesia. \\ ${ }^{3}$ Pendidikan Teknik Bangunan, FT UNJ, Jakarta, Indonesia \\ ${ }^{*}$ Corresponding author :
}

\begin{abstract}
This study aims to explore relations in the knowledge base for thr theory and application of work practieson the bench so asto create the correspondence between the basic knowledge learned by practice to be implemented, therefore students need to get enough stock in the understanding of the sciences that are taught in subjects construction Work bench Wood and Practice.

In this research, conducted research at the SMKN 58 Jakarta by using quqsy experimental method, and the sample consisted of class $X$ Program Wood Constructions Engineering Expertise as many as 31 students. Instruments used in this study is a test. These instruments use objective tests with four alternative answers to 30 questions. Aspects are measured in this testknowledge, while for measuring the value of work practice used bench practice that has been done by the class $X$ Program Technical Expertise in Wood Construction SMKN 58 Jakarta. Once the instrument is made then tested the validity and reliabilityof the students outside of the sample, because the studied samples in the selected schools to test the validity and reliability SMKN 1 Cibinong, after the validity and reliability analysis was then performed grain matter and techniques of data analysis, data analysis techniques used in this study is regression.
\end{abstract}

Based on the studies indicates that there is a positive relations between the Knowledge Base Construction Wood Bench Practice Learning Outcomes. The degree of association between variables Knowledge Base Construction Wood Bench Work Practice Learning Outcomes can be seen from the value of the correlation coefficient (rxy) of 0.470. This illustrates that the relations between the Knowledge Base Construction Wood Bench Work Practice Learning Outcomes are linked. Knowlwdge Base Construction Wood only slightly contribute to the high and low result Intern Learning Bench, that means the higher the Knowledge Base Wood Construction students, the higher the bench Work Practice Learning Outcomes.

\section{Keyword :}




\section{PENDAHULUAN}

Di SMKN 58 Jakarta, mata pelajaran Konstruksi Kayu dan Praktek Kerja Bangku merupakan mata pelajaran yang wajib diikuti oleh siswa kelas X-XII, Program Keahlian Teknik Konstruksi Kayu (TKK). Pada mata pelajaran Konstruksi Kayu, Standar Kompetensi yang digunakan yakni, membuat sambungan dan hubungan kayu, dan Kompetensi Dasar yang digunakan yakni, mendeskripsikan pembuatan sambungan dan hubungan kayu, melukis pembuatan sambungan dan hubungan kayu, dan membuat sambungan dan hubungan kayu. Adapun Standar Kompetensi yang digunakan pada mata pelajaran Praktek Kerja Bangku yakni, merencanakan pekerjaan konstruksi kayu, dengan Kompetensi Dasar, merencanakan proses pelaksanaan dan penyelesaian pekerjaan konstruksi kayu.

Meskipun perencanaan pembelajaran telah disusun, karena adanya keterbatasan, dalam pelaksanaan pembelajaran terkadang dalam penerapannya pemberian materi tidak sesuai dengan apa yang akan dipraktekan. Setelah mendapatkan informasi dari pihak sekolah mengenai sebab dari ketidak sesuaian antara mata pelajaran Konsruksi Kayu dengan Praktek Kerja Bangku, hal tersebut dikarenakan pihak sekolah ingin sebuah benda jadi yang dapat dijual kembali, sehingga siswa tidak mendapat kesesuaian antara pengetahuan dasar teori dan prakteknya.

Adanya keinginan untuk
mencari hubungan pada
pengetahuan dasar untuk teori
Konstruksi Kayu dan pada aplikasi
Praktek Kerja Bangku sehingga
tercipta kesesuaian antara
pengetahuan dasar yang dipelajari
dengan praktek yang akan
dilaksanakan, maka dari itu siswa
perlu mendapat bekal yang cukup
dalam memahami ilmu-ilmu yang
dipelajari pada mata pelajaran
Konstruksi Kayu dan Praktek Kerja
Bangku.

\section{METODE PENELITIAN}

Metode penelitian yang akan digunakan adalah metode eksperimental kuasi, yakni penelitian yang mendekati sungguhan dimana tidak mungkin mengadakan kontrol atau memanipulasikan semua variabel yang relevan.

\section{HASIL PENELITIAN DAN PEMBAHASAN}

Hasil
dimaksudkan untuk memberikan
gambaran umum mengenai
penyebaran atau distribusi data.
Skor yang akan disajikan setelah
diolah dari data mentah
menggunakan statistik deskriptif
yaitu skor rata-rata dan simpangan
baku.

$\begin{array}{ccc} & \text { Berdasarkan jumlah } \\ \text { variabel dan merujuk kepada }\end{array}$


masalah penelitian, maka deskripsi data dapat dikelompokkan menjadi dua bagian sesuai dengan jumlah variabel penelitian. Kedua bagian tersebut adalah pengetahuan dasar Konstruksi Kayu sebagai variabel bebas (independent variabel) dan Hasil Belajar Praktik Kerja Bangku sebagai variabel terikat (variable dependent).

Dari hasil perhitungan validitas terdapat 11 item pertanyaan yang dinyatakan non valid karena nilai $r_{\text {hitung }}<r_{\text {tabel. }}$. Maka, peneliti membuang soal yang tidak valid tersebut dan menggunakan item pertanyaan valid untuk diujikan kepada sampel penelitian yaitu sebanyak 30 item pertanyaan

Selanjutnya untuk uji reliabilitas, berdasarkan hasil perhitungan manual dengan Rumus Alpha dan menggunakan Program SPSS versi 16 diperoleh nilai reliabilitas sebesar 0,818 , hasil perhitungan lengkap dapat diperoleh pada lampiran 6 hal.117. Dengan nilai sebesar 0,818 mengindikasikan bahwa reliabilitas tersebut tergolong sangat tinggi, artinya ketika test tersebut diujikan dalam waktu yang berbeda, akan menunjukkan hasil yang relatif sama.

Tabel 1. Distribusi Frekuensi Pengetahuan Dasar Konstruksi Kayu sebagai Variabel Bebas

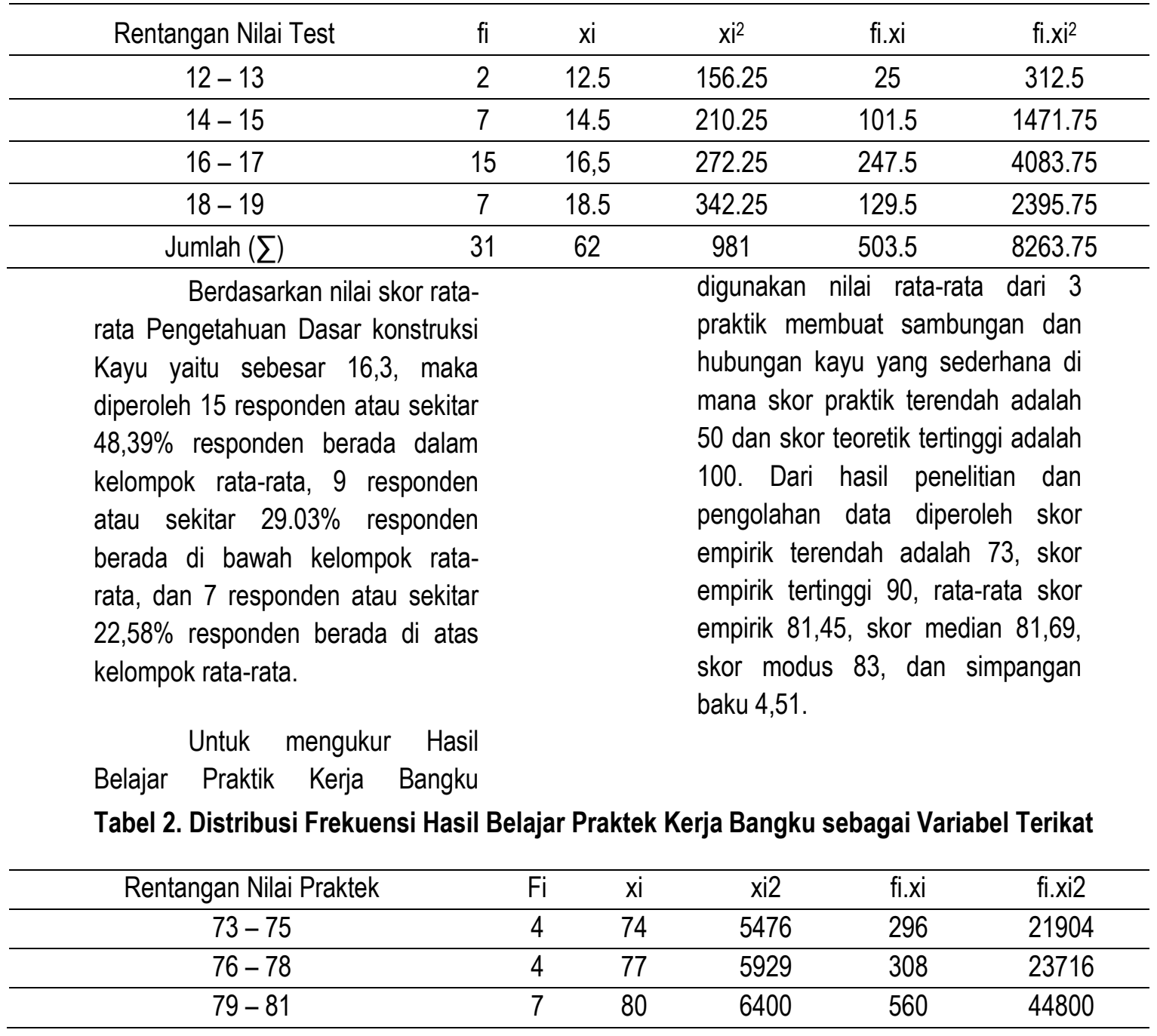




\begin{tabular}{|c|c|c|c|c|c|}
\hline Rentangan Nilai Praktek & $\mathrm{Fi}$ & $x i$ & xi2 & fi.xi & fi.xi2 \\
\hline $82-84$ & 8 & 83 & 6889 & 664 & 55112 \\
\hline $85-87$ & 5 & 86 & 7396 & 430 & 36980 \\
\hline $88-90$ & 3 & 89 & 7921 & 267 & 23763 \\
\hline Jumlah $(\Sigma)$ & 31 & 489 & 40011 & 2525 & 206275 \\
\hline $\begin{array}{l}\text { Berdasarkan nilai skor rata- } \\
\text { rata Hasil Belajar Praktik Kerja } \\
\text { Bangku yaitu sebesar } 81,45 \text {, maka } \\
\text { diperoleh } 7 \text { responden atau sekitar }\end{array}$ & & & $\begin{array}{l}\text { sebesar } \\
\text { sebesar } \\
\text { faktor lain } \\
\text { gaya men }\end{array}$ & $\begin{array}{l}\%, \quad d \\
\% \text { dite } \\
\text { ti kom } \\
\text { turu. }\end{array}$ & $\begin{array}{l}\text { sisanya } \\
\text { n oleh } \\
\text { si guru, }\end{array}$ \\
\hline
\end{tabular}

$22,60 \%$ responden berada dalam kelompok rata-rata, 8 responden atau sekitar $25,80 \%$ responden berada di bawah kelompok rata-rata, dan 16 responden atau sekitar $51.60 \%$ responden berada diatas kelompok rata-rata.

Dari hasil perhitungan menggunakan perhitungan manual dan Program SPSS versi 16 didapat koefisien korelasi $\left(r_{x y}\right)$ sebesar 0,470 . Dengan nilai koefisien korelasi tersebut dapat diinterpretasikan bahwa hubungan Pengetahuan Dasar Konstruksi Kayu dengan Hasil Belajar Praktik Kerja Bangku tergolong substansial atau sedang.

$$
\text { Besarnya hubungan }
$$

Pengetahuan Dasar Konstruksi Kayu dengan Hasil Belajar Praktik Kerja Bangku ditentukan oleh koefisien determinasi $\left(r_{x y}{ }^{2}\right)$. Berdasarkan perhitungan diperoleh koefisien determinasi $\left(r_{x y}{ }^{2}\right)$ yaitu 0,2209 atau $22,09 \%$. Ini berarti bahwa meningkat atau menurunkan Hasil Belajar Praktik Kerja Bangku 22,09\% dapat dijelaskan oleh besarnya Pengetahuan Dasar Konstruksi Kayu melalui hubungan linear yang persamaannya adalah $\hat{Y}$ $=60,579+1,265 \mathrm{x}$ atau dengan kata lain pengaruh Pengetahuan Dasar Konstruksi Kayu terhadap Hasil Belajar Praktek Kerja Bangku

\section{KESIMPULAN DAN SARAN}

\section{Kesimpulan}

Berdasarkan deskripsi, analisis, dan interpretasi data yang telah diuraikan pada bab-bab sebelumnya, dapat ditarik kesimpulan sebagai berikut :

1. Hasil penelitian ini menunjukkan bahwa terdapat hubungan positif antara Pengetahuan Dasar Konstruksi Kayu dengan Hasil Belajar Praktik Kerja Bangku dengan taraf kepercayaan 95 persen. Artinya jika terdapat 100 responden yang dijadikan sampel, maka kemungkinan terdapat kesalahan adalah 5 responden.

2. Derajat hubungan antara variabel Pengetahuan Dasar Konstruksi Kayu dengan Hasil Belajar Praktik Kerja Bangku dapat dilihat dari nilai koefisien korelasi $\left(r_{x y}\right)$ sebesar 0,470 . Hal ini menggambarkan bahwa hubungan antara Pengetahuan Dasar Konstruksi Kayu dengan Hasil Belajar Praktik Kerja Bangku memiliki hubungan substansial. Pengetahuan Dasar Konstruksi Kayu yang ada pada siswa hanya sedikit 
memberikan kontribusi terhadap tinggi rendahnya Hasil Belajar Praktik Kerja Bangku, namun itu sama artinya semakin tinggi Pengetahuan Dasar Konstruksi Kayu siswa, maka semakin tinggi pula Hasil Belajar Praktik Kerja Bangku.

3. Besarnya kontribusi Pengetahuan Dasar Konstruksi Kayu terhadap Hasil Belajar Praktik Kerja Bangku ditentukan oleh koefisien determinasi. Besarnya koefisien determinasi adalah 0,2209 atau 22,09\%. Nilai koefisien determinasi sebesar 22,09\% memberikan pengertian bahwa meningkat atau menurunkan hasil belajar Praktik Kerja Bangku 22,09\% dapat dijelaskan oleh besarnya Pengetahuan Dasar Konstruksi Kayu melalui hubungan linear yang persamaannya adalah $\hat{Y}$ $=60,579+1,265 x$ atau dengan kata lain kontribusi pengetahuan dasar terhadap hasil belajar sebesar 22,09\%, dan sisanya sebesar $77,91 \%$ ditentukan oleh faktor lain seperti kompetensi guru, gaya mengajar guru.

\section{Saran}

Berdasarkan kesimpulan di atas dapat dikemukakan saransaran sebagai berikut :

1. Perlunya penerapan yang sesuai antara pelaksanaan pembelajaran dengan perencanaan pembelajaran yang telah disusun, sehingga ada kesesuaian antara pengetahuan dasar konstruksi kayu dengan hasil belajar praktik kerja bangku.

2. Dalam menyampaikan materi ada baiknya guru mata pelajaran Pengetahuan Dasar Konstruksi Kayu memiliki kemampuan untuk membuat siswa lebih fokus dalam belajar, misalnya guru memperhatikan keadaan siswa dalam belajar, apabila suasana kelas kurang kondusif seperti kelas yang rebut, siswa yang mengobrol, ataupun siswa yang justru bermain ponsel saat belajar. Suasana kelas yang nyaman akan dapat memaksimalkan materi yang akan disampaikan.

3. Guru mata pelajaran Pengetahuan Dasar Konstruksi Kayu diharapkan memiliki inovasi dalam penyampaian materi ajar, seperti pembuatan madia ajar yang baik, kreatif dan mudah di mengerti oleh siswa

4. Dalam setiap akhir pemberian materi pelajaran Pengetahuan Konstruksi Dasar Konstruksi kayu sebaiknya guru mengulang materi tersebut dengan beberapa pertanyaan ringan yang mudah dimengerti, ataupun dengan tes singkat yang tidak membuat siswa terbebani oleh tes-tes tersebut.

\section{DAFTAR PUSTAKA}

Arikunto, Suharsimi. 2002. Prosedur Penelitian. Jakarta. Rineka Cipta

Blogspot. 2010. Teknik Analisis Data. [Terhubung Berkala] http://skripsimahasiswa.blogspot.c om/2010/11/teknik-analisisdata.html. [11 November 2011] 
Gurupenghubung. 2011. Panduan Analisis Butir Soal. [Terhubung Berkala] http://gurupembaharu.com/home/ ?p=4917. [11 November 2011]

Haryati, Mimin. 2009. Model dan Teknik Penilaian pada Tingkat Satuan Pendidikan. Jakarta. Gaung Persada Press Jakarta

Iriani, Tuti. 2008. Perencanaan Pembelajaran. Jakarta

Moleong. J Lexy. 1994. Metodologi Penelitian Kualitatif. Bandung. Remaja Rosdakarya

Purwanto M, Ngalim. 2007. IImu Pendidikan toritis dan Praktis. Bandung. Remaja Rosdakarya

Pusat Bahasa Depdiknas. 2007. Kamus Besar Bahasa Indonesia. Ed ke-3

Puspitahati, Ria. 2005. Hubungan Pengetahuan Teori IImu Ukur Tanah 1 dengan Praktek IImu Ukur Tanah 1 pada Mahasiswa S1 Jurusan Teknik Sipil Universitas Negri Jakarta.
Jakarta: Fakultas Teknik, Universitas Negri Jakarta

Sudjana. 1992. Teknik Analisis Regresi dan Korelasi bagi para peneliti. Bandung. Tarsito

Sudjana, Nana. 2004. Penilaian Hasil Proses Belajar Mengajar. Bandung. Remaja Rosdakarya

Sugiyono. 2007. Metode Penelitian Pendidikan. Bandung. Alfabeta

Sugiyono. 2011. Statistika Penelitian Pendidikan. Bandung. Alfabeta

Sukmadinata, Nana Syaodih. 2008. Metode Penelitian Pendidikan. Bandung. Remaja Rosdakarya

Sutrisno, Hadi. 1986. Metode Research. Jakarta. Andi Offset

Utami, Munandar. 1999. Kreatifitas Sepanjang Masa. Jakarta. Pustaka Sinar Harapan

Usman, Husaini. 1995. Pengantar Statistik. Jakarta. Bumi Aksara 